\title{
Palaeoecology and Forager Subsistence Strategies during the Pleistocene-Holocene Transition: A Reinvestigation of the Zooarchaeological Assemblage from Spirit Cave, Mae Hong Son Province, Thailand
}

\author{
$\boldsymbol{\Delta} \cdot \boldsymbol{\Delta} \cdot \boldsymbol{\Delta}$ \\ CYLER CONRAD, CHARLES HIGHAM, MASAKI EDA, \\ AND BEN MARWICK
}

\section{INTRODUCTION}

THIS YeAR, 2016, MARKS THE FIFTIETH ANNIVERSARY of Chester Gorman's excavation of Spirit Cave (Tham Phii Man), a small site high on a cliff overlooking the Khong stream in northwest Thailand (Gorman 1969, 1970, 1971a, 1971b). ${ }^{1}$ Spirit Cave quickly became one of the best-known and most significant prehistoric sites in Southeast Asia (Solheim 1972). With deposits spanning the Pleistocene-Holocene transition, this site provided the first opportunity to understand prehistoric human adaptations prior to the emergence of agriculture. Recovery and analysis of faunal and botanical remains greatly advanced knowledge of subsistence strategies in this highland region of Mainland Southeast Asia (Gorman 1971a, 1971b; Solheim 1972; Yen 1977), but left several questions unanswered (Flannery 1973).

While Gorman (1971b) provided a summary Minimum Number of Individuals (MNI) count of the faunal remains, the assemblage was not statistically analyzed. Gorman only conducted a qualitative analysis of the fauna and associated artifacts to argue that Spirit Cave was occupied relatively continuously in Layers 2, 2a, and 4, which span the Pleistocene-Holocene transition. Our reinvestigation of the faunal assemblage therefore focuses on two main questions. First, how complete is the zooarchaeological assemblage and has the entire assemblage been preserved from the original excavations? Second, do the archaeofauna support Gorman's original arguments for site use and occupation during the Pleistocene-Holocene transition?

Cyler Conrad is a Ph.D. student in the Department of Anthropology, University of New Mexico, U.S.A. Charles Higham is a professor of archaeology in the Department of Anthropology and Archaeology, University of Otago, New Zealand. Masaki Eda is a lecturer at the Hokkaido University Museum, Hokkaido University, Japan. Ben Marwick is a senior research fellow, Center for Archaeological Science, University of Wollongong, Australia. 
Our re-identification and quantitative analysis suggest that Spirit Cave saw periods of sporadic occupation and use instead of the relatively continuous occupation argued by Gorman (1970). New species-level identifications, including of roundleaf bats (Hipposideros larvatus and bicolor), elongated tortoise (Indotestudo elongata), black marsh turtle (Siebenrockiella crassicollis), Burmese hare (Lepus cf. peguensis), and a potential red junglefowl (Phasianidae-? Gallus gallus) support our interpretation and broaden our understanding of the human occupation of Spirit Cave.

\section{BACKGROUND AND RESEARCH DESIGN}

Spirit Cave is located in the karstic upland region of Mae Hong Son Province, northwest Thailand (Gorman 1970:79, 1971b:65-67) (Fig. 1). After local hunters informed Gorman of the presence of the site, he began a systematic survey in the spring of 1966 (1971b:66). An initial survey of the three chambers that comprise the cave complex suggested an intact and rich archaeological deposit in the middle cave section (Gorman 1971b:66-67) (Fig. 2). Originally named Site 19, the middle cave proved promising for archaeological excavation, with cord-marked pottery sherds, flakes, and quartzite cores visible on the surface (Gorman 1971b:68). With this information, Gorman returned to excavate the site between June and July 1966 $(1971 b: 65-67) .^{2}$

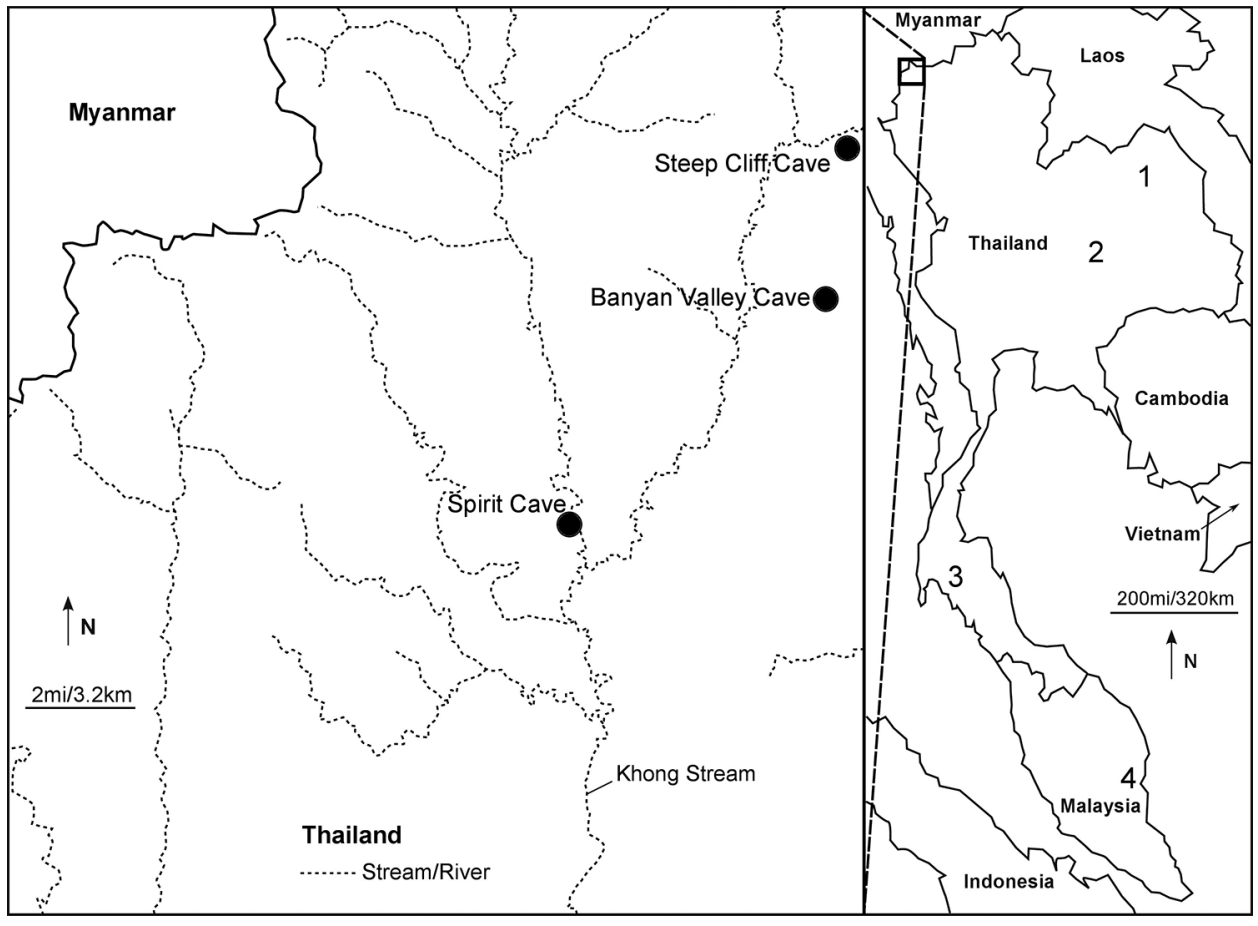

Fig. 1. Location of Mainland Southeast Asian sites discussed in the text. 1) Ban Chiang; 2) Ban Non Wat; 3) Lang Rongrien and Moh Khiew Cave II; 4) Gua Sagu. 


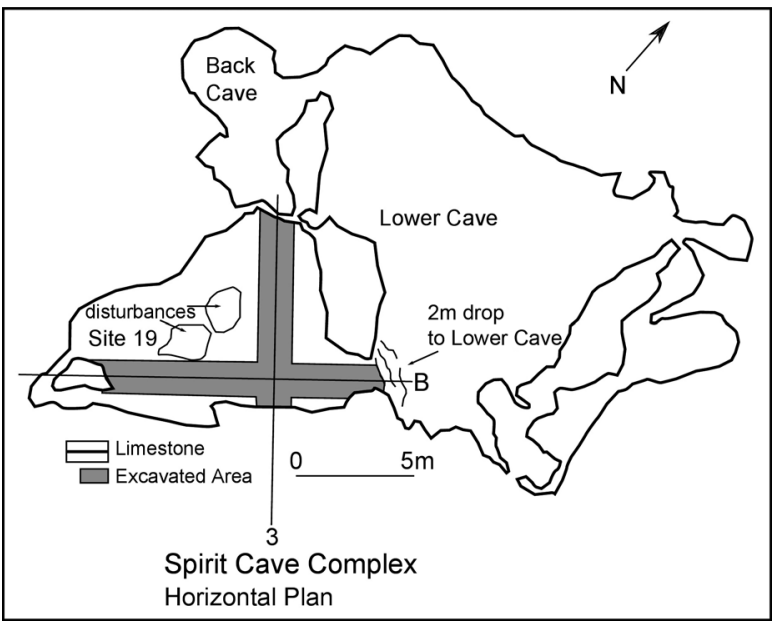

Fig. 2. Horizontal site plan for Spirit Cave, modified from Gorman $(1970: 89)$.

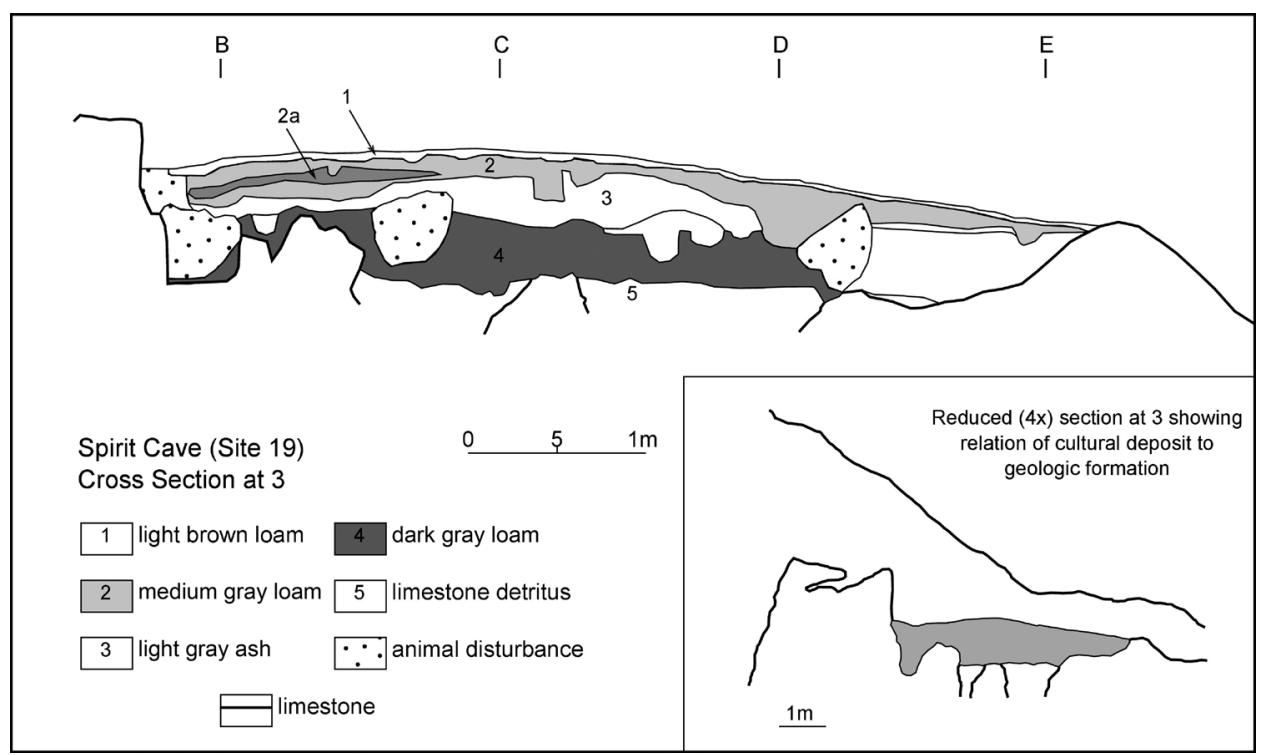

Fig. 3. Stratigraphic profile for Spirit Cave, modified from Gorman (1970:90).

Excavation used $1 \mathrm{~m}$ squares following the natural strata (Gorman 1971b:69). Non-excavated $50 \mathrm{~cm}$ baulks left between squares provided the ability to reconstruct stratigraphic relationships and wall profiles (Gorman 1971b:69). This process revealed 5 layers at the site (Gorman 1971b:70-73) (Fig. 3). Using fine-grained screening (1 mm mesh), Gorman recovered abundant samples of bamboo charcoal. He sent 14 samples for radiocarbon dating, nine of which were eventually published (Gorman 1971b:70, 112) (Table 1). These dates provided one of the first systematic chronological sequences in Mainland Southeast Asia (Gorman 1969; Higham 1972; Pookajorn 1988) (Fig. 4). 
Table i. Spirit Cave Site Chronology and Dated Stratigraphic Sequence

\begin{tabular}{llllc}
\hline LAYER & & \multicolumn{1}{c}{ UNCAL } & & $\begin{array}{c}\text { CAL }{ }^{\mathrm{I}} \mathrm{C} \text { B.P. } \\
(95 \% \text { INTERVALS })\end{array}$ \\
\hline 1 & LAB NUMBER & ${ }^{\mathrm{I} 4} \mathrm{C} \pm \mathrm{I} \sigma$ B.P. & REFERENCE & $3356-3160$ \\
1 & OxA-10271 & $3042 \pm 37$ & Lampert et al. 2003 & $3335-3061$ \\
1 & OxA-10272 & $2995 \pm 40$ & Lampert et al. 2003 & $8974-7666$ \\
2 & FSU 317 & $7400 \pm 300$ & Gorman 1970 & $9661-7945$ \\
2 & FSU 314 & $7905 \pm 390$ & Gorman 1970 & $10,160-9092$ \\
$2 \mathrm{a}$ & GaK 1846 & $8550 \pm 200$ & Gorman 1970 & $10,414-8590$ \\
$3 / 4$ & FSU 318 & $8520 \pm 290$ & Gorman 1970 & $15,199-11,315$ \\
4 & FSU 315 & $11,350 \pm 560$ & Gorman 1970 & $11,286-9471$ \\
4 & GaK 1845 & $9180 \pm 360$ & Gorman 1970 & $14,030-11,166$ \\
\hline
\end{tabular}

Samples dated by Gorman (1970:98-101) are charcoal, generally from bamboo. Two contested organic resin-coating dates are from ceramic sherds (Lampert et al. 2003). Radiocarbon date ranges were calibrated using Bchron 4.1.1 (Parnell 2014) and IntCal 13 curve (Reimer et al. 2013). Two dates from the Tata Institute of Fundamental Research are not listed here since the uncalibrated dates were not provided by Gorman (1970: 99).

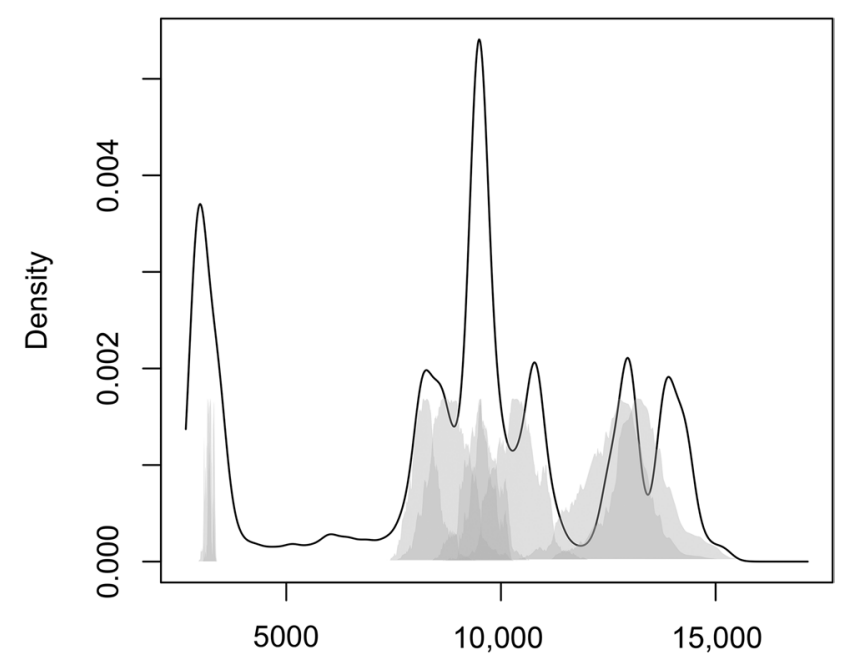

Age (cal years B.P.)
Fig. 4. Radiocarbon age density plot for Spirit Cave. Higher density areas (darker grey shading) represent time periods most likely to be represented by the dated samples. These may correspond to periods of increased human activity at the site.

There is an important exception to the Spirit Cave chronology, however. A recent dating of resin coating on ceramic sherds found in Layer 1 suggests that the original bamboo charcoal dates for the uppermost stratum are too early (Lampert et al. 2003). Because these dates remain contested (Lampert et al. 2004; White 2004), our discussion on the zooarchaeological assemblage from Layer 1 is limited in scope. Despite this caveat, the Spirit Cave chronology remains significant because it was the first site in Mainland Southeast Asia reliably dated to the Pleistocene-Holocene transition (Gorman 1969; Higham 1972).

Materials collected from Spirit Cave also provided the first insights into huntergatherer adaptations for this region during this period. Gorman (1971a, 1971b) made 
four primary arguments based upon the faunal assemblage and associated artifacts. First, Gorman argued that hunter-gatherers exploited a diverse resource base including fauna from almost all environmental zones (terrestrial, arboreal, and aquatic). Second, the presence of both wet season gastropods and dry season freshwater bivalves indicated that hunter-gatherers occupied Spirit Cave year-round. Third, the homogenous deposits in Layers 2, 2a, and 4 led Gorman to claim that there was a relatively continuous human occupation for "a considerable period of time" in these layers, but not in Layers 1 and 3 (1970:93). Finally, although the botanical remains were not domesticated types, he argued that they provided the earliest evidence of plant exploitation and possible cultivation in Mainland Southeast Asia (Gorman 1971b:27-28; Yen 1977). His conclusions shaped ideas concerning the nature of prehistoric foraging adaptations throughout Mainland Southeast Asia (Flannery 1973:284-287; Glover 1977; Higham 1972; Pookajorn 1988; Reynolds 1990; Shoocongdej 2000; Solheim 1972; Yen 1977).

While Spirit Cave remains an important site in the prehistoric record of Southeast Asia, the lack of a statistical analysis of the zooarchaeological assemblage hampers the accurateness of our understanding of the true nature of hunter-gatherer subsistence adaptations during the Pleistocene-Holocene transition and thereafter. Our reanalysis therefore focuses on testing the faunal components of Gorman's arguments. Specifically, we examine whether or not there is evidence of exploitation of a diverse set of resources that would indicate continual, year-round use of the site.

Published accounts of the site fauna include both MNI (Higham 1971:133-136, 1977:389-394) and presence/absence data (Brandt 1971 :137) (Tables 2, 3). ${ }^{3}$ An additional goal of this reanalysis is the quantification of Spirit Cave fauna as Number of Identified Specimens (NISP) to statistically investigate shifting patterns in the faunal assemblage over time (Grayson 1984:16-90; Lyman 2008:21-81). We also reexamine the overall composition of the faunal assemblage to establish how much original material is preserved from the site, and whether or not the remaining specimens support or refute Gorman's original arguments on subsistence diversity, forager occupation, and seasonal use.

\section{METHODS}

NISP is the primary measure of taxonomic abundance employed in our analysis (Lyman 2008), although we also calculated MNI counts and have published this dataset elsewhere (Conrad 2015b). Here, we limit our discussion to NISP values for several reasons. Of the many problems affecting these numerical units, specimen interdependence for NISP and aggregation for MNI are the most serious (Grayson 1984:16-92; Lyman 2008:21-82). Interdependence affects NISP values because a single skeletal element can be fragmented several times (among other factors), leading the zooarchaeologist to count a single elemental specimen multiple times. This leads to inflated counts (just as MNI results in undercounts). Aggregation affects MNI because zooarchaeologists aggregate fauna into distinct and sometimes arbitrary groups using spatial or temporal criteria (Lyman 2008:58). For example, since MNI must be calculated using all specimens identified to a unique taxon within a defined context, how units (vertical or horizontal) are selected will determine the ultimate MNI value. True taxonomic abundance is impossible to derive, but falls somewhere between MNI and NISP values (Grayson 1984; Lyman 2008).

The Spirit Cave faunal assemblage suffers from two distinct aggregation problems: (1) differential aggregation of MNI counts per layer between the originally published 
Table 2. The Original Spirit Cave Archaeofaunal Assemblage Published in Gorman's Ph.D. Dissertation (I97i $b$ ).

\begin{tabular}{|c|c|c|c|c|c|c|c|c|c|}
\hline $\begin{array}{l}\text { TAXONOMIC } \\
\text { CLASSIFICATION }\end{array}$ & $\begin{array}{c}\text { LAYER } \\
\text { I }\end{array}$ & $\begin{array}{c}\text { LAYER } \\
\text { IA }\end{array}$ & $\begin{array}{l}\text { LAYER } \\
2\end{array}$ & $\begin{array}{c}\text { LAYER } \\
2 \mathrm{~A}\end{array}$ & $\begin{array}{c}\text { LAYER } \\
3\end{array}$ & $\begin{array}{c}\text { LAYER } \\
3 \mathrm{~A}\end{array}$ & $\begin{array}{c}\text { LAYER } \\
4\end{array}$ & $\begin{array}{c}\text { LAYER } \\
5\end{array}$ & $\Sigma$ \\
\hline Cyclophorus volvulus & $\mathrm{x}$ & & & & & & & & \\
\hline Cyclophorus siamensis & $\mathrm{X}$ & $\mathrm{X}$ & $\mathrm{X}$ & $\mathrm{X}$ & & & $\mathrm{X}$ & $\mathrm{X}$ & \\
\hline Rhiostoma sp. & $\mathrm{X}$ & & $\mathrm{X}$ & & & & & & \\
\hline Aegista (Plestotropis) sp. & $\mathrm{x}$ & & & & & & & & \\
\hline Ganesella sp. & $\mathrm{X}$ & & $\mathrm{X}$ & & & & & & \\
\hline Margaritanopsis laosiensis & $\mathrm{X}$ & & $\mathrm{X}$ & & & $\mathrm{X}$ & $\mathrm{X}$ & $\mathrm{X}$ & \\
\hline Siphonocyclotus sp. & & & $\mathrm{X}$ & & & & & & \\
\hline Megaustenia praestans? & & & $\mathrm{X}$ & & & & & & \\
\hline Centropodia (Arthropoda) & & & $\mathrm{X}$ & & & & & & \\
\hline Bovine & & & & & 1 & & & 1 & 2 \\
\hline Bat & 2 & & 5 & & 8 & & 5 & & 20 \\
\hline Cervid & 1 & & 1 & & 1 & & 2 & & 5 \\
\hline Rat & 1 & & 1 & & 1 & & 1 & & 4 \\
\hline Big lizard & 7 & & 12 & & 4 & & 7 & & 30 \\
\hline Fish & 2 & & 8 & & 5 & & 3 & & 18 \\
\hline Suid & 2 & & 2 & & 1 & & & 1 & 6 \\
\hline Turtle (NISP)* & 6 & & 18 & & 7 & & & & 31 \\
\hline Small carnivora & & & 2 & & & & & & 2 \\
\hline Rodent & 1 & & 1 & & & & & & 2 \\
\hline Snake & & & 1 & & 1 & & & & 2 \\
\hline Bird & 1 & & & & 2 & & & & 3 \\
\hline Ground squirrel & 1 & & & & & & & & 1 \\
\hline Primate & 1 & & 1 & & 1 & & 1 & 1 & 5 \\
\hline$\Sigma$ & 25 & & 52 & & 32 & & 19 & 3 & 129 \\
\hline
\end{tabular}

The horizontal bar mid-table separates invertebrates from vertebrates.

* Turtle carapace represented as NISP (Higham in Gorman 1971b:136).

assemblage and our own; and (2) lack of information on how MNI counts were initially calculated. The original MNIs published in Gorman (1971b:133-137) are listed in Layers 1, 2, 3, 4, and 5 for the vertebrate assemblage and Layers 1, 1a, 2, 2a, 3a, 4, and 5 for the invertebrate assemblage. Based on available provenience information, we identified taxa in Layers $1,2,2 \mathrm{a}, 3$, and 4 in our reanalysis. The MNI values in Gorman's (1971b) dissertation are therefore not comparable to our MNI values due to differences in aggregation between stratigraphic layers and because we lack documentation of the units used in Gorman's original publication. We cannot remedy this problem, which is a common issue with the use of MNI (Grayson 1984; Lyman 2008). The second problem is our lack of knowledge on how MNI values were calculated from the original assemblage, since this information was not published with the original counts (Gorman 1971b). Without a clear understanding of how each investigator identified MNI counts, it is virtually impossible to replicate earlier analyses.

Not only are MNI values differentially recorded for the layers and the original criteria for MNI calculation unknown, another problem with using MNI lies in the incompleteness of the Spirit Cave assemblage. After an interval of 48 years and 4 different storage locations at the University of Otago, only part of the original collection has been located. This information is significant to our second point: because the 
Table 3. Summary of Spirit Cave Archaeofaunal Assemblage as Presence (+)/Absence (-)

\begin{tabular}{|c|c|c|c|c|c|}
\hline $\begin{array}{l}\text { TAXONOMIC } \\
\text { CLASSIFICATION }\end{array}$ & COMMON NAME & LAYER I & LAYER 2 & LAYER 3 & LAYER 4 \\
\hline Sus scrofa jubatus & Wild boar & + & + & + & - \\
\hline Axis porcinus & Pig deer & - & - & + & + \\
\hline Cervus unicolor & Sambar deer & + & + & + & + \\
\hline Presbytis sp. & Langur & + & + & + & + \\
\hline Macaca sp. & Macaque & + & + & + & + \\
\hline Macaca assamensis & Assam macaque & - & - & + & - \\
\hline Presbytis obscura & Dusky langur & + & + & - & - \\
\hline Presbytis cristata & Crested langur & + & - & - & - \\
\hline Hylobates sp. & Gibbon & + & + & + & + \\
\hline Nycticebus coucang & Slow loris & - & - & - & + \\
\hline Paradoxurus hermaphroditus & Common palm civet & + & + & + & + \\
\hline Hemigalus derbyanus & Banded palm civet & - & + & - & - \\
\hline Felis viverrina & Fishing cat & - & - & + & - \\
\hline Felis bengalensis & Leopard cat & + & - & - & - \\
\hline Arctonyx collaris & Hog badger & + & + & + & + \\
\hline Lutra sp. & Otter & - & - & + & - \\
\hline Martes flavigula & Marten & - & + & - & + \\
\hline Petaurista petaurista & Flying squirrel & - & - & + & - \\
\hline Cannomys badius & Lesser bamboo rat & + & - & - & - \\
\hline Rhyzomys sumatrensis & Hoary bamboo rat & - & + & - & + \\
\hline Hystryx sp. & Porcupine & - & + & + & - \\
\hline Rattus sp. & Rat & + & + & + & + \\
\hline Callosciurus sp. & Squirrel & + & - & - & - \\
\hline Hipposideros sp. & Bat & + & + & + & + \\
\hline Acrossocheilus sp. & Carp & + & + & + & + \\
\hline Agamidae & Lizard & + & - & - & + \\
\hline Emydidae & Turtle & + & + & + & - \\
\hline Potamonidae & Crab & + & + & + & + \\
\hline
\end{tabular}

From Higham $1977:$ 390-391.

Spirit Cave assemblage is a subset of the original collection, it does not represent the complete assemblage.

Even if the original Spirit Cave excavations recovered all fauna present at the site, which is almost certainly untrue (Lyman 1994), there were three periods when partial loss of the assemblage could have occurred (Fig. 5b, c, d). There may have been loss during the original movement and shipment of the faunal assemblage from Spirit Cave to the University of Hawai'i, sometime between 1966 and 1968 (Fig. 5b); there may have been loss or incomplete shipment of the faunal assemblage from Hawai' $i$ to the University of Otago in 1968 (Fig. 5c); and there may also have been loss or misplacement at the curation site of the University of Otago, since the bones were moved on multiple occasions (Fig. 5d). ${ }^{4}$ Although all the bones present at the University of Otago were shipped to the University of New Mexico without any loss in 2014, our reanalysis deals with only a minute portion of the original assemblage excavated and recovered by Gorman. ${ }^{5}$ This is a common issue with older collections (Jones and Gabe 2015), but the complexity of the Spirit Cave assemblage makes it likely that the loss has been significant.

Finally, and most importantly, we focus on NISP as the primary measure of taxonomic abundance at the site because of the questions we are interested in addressing. 


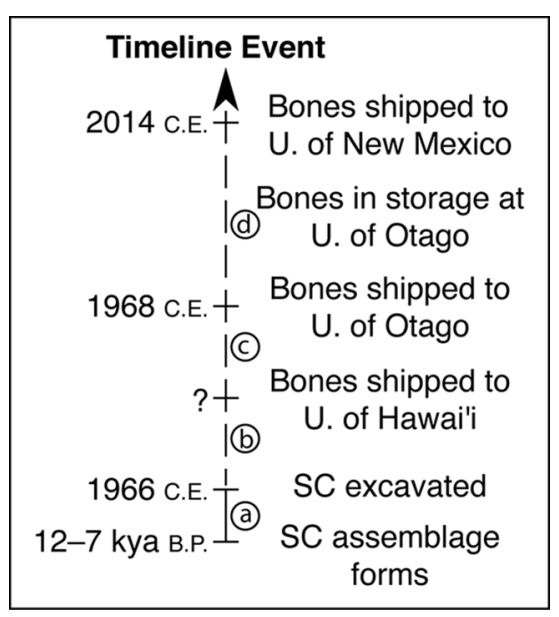

Fig. 5. Spirit Cave faunal assemblage life history. Periods and events discussed in the text are designated by circled letters $\mathrm{a}-\mathrm{d}$. Solid vertical lines designate periods of little to no loss of fauna. Dashed vertical lines designate periods of possible faunal loss.

Both NISP and MNI are burdened by analytical costs and benefits, but the major problem with NISP (i.e., inflation of counts due to specimen interdependence) is actually useful for our analysis. For example, since we know that this is not the complete assemblage, using NISP allows us to investigate the maximum abundance of taxa at the site. If we were to focus on MNI counts, then we would only be providing a minimum abundance of taxa at the site, which in essence would be fragmenting the assemblage further by limiting the absolute number of faunal specimens, or taxa, analyzed and reported. Additionally, the types of questions that are commonly examined using MNI such as skeletal element representation or meat weights are not under investigation here (Grayson 1984; Lyman 2008). Thus, NISP provides the best possible measure of overall taxonomic abundance for this project. We use NISP based on relative abundance to calculate several measures of the compositional, ecological, and subsistence characteristics of this assemblage. We also examine evidence for bone burning, human butchering (cut marks), and rodent gnawing.

In 2014, the remaining faunal material from the Spirit Cave assemblage was shipped from the University of Otago to the University of New Mexico for identification and reanalysis. Each specimen was recorded with a catalogue number, provenience information, taxonomic identification, element, side, portion, count (NISP/MNI), mass (grams), burning (charred/calcined/both), modification, and cut marks. Cyler Conrad identified the mammals, reptiles, gastropods, bivalves, and the single human specimen using the University of New Mexico Museum of Southwestern Biology comparative collections and the Natural History Museum of Thailand comparative collections and standardized texts (Brandt 1974; Lekagul and McNeely 1988). Masaki Eda identified the birds using the Hokkaido University Museum comparative collections, and his and Kazuto Kawakami's (Forestry and Forest Products Research, Japan) personal collections. Peter Ng identified the crab specimens at the Raffles Museum of Biodiversity (Lee Kong Chian Natural History Museum) using the Singapore comparative collections. Rachanie Thosarat identified fish remains using her own comparative collections from northern Thailand. All faunal material is stored in reclosable $4 \mathrm{~mL}$ polyethylene sample bags for permanent curation. Cataloging followed a numerical system beginning at SC-00001 and ending with SC-00341 for faunal specimens. All eco/artifact databases and script for analyses conducted in $\mathrm{R}$ version 3.1.1 
(R Development Core Team 2014) and RStudio (2014) version 0.98.1028 are available in an online digital repository at http://hdl.handle.net/1928/26730 (Conrad 2015b).

\section{COMPOSITION OF THE FAUNAL ASSEMBLAGE}

As discussed above, it was clear from the onset that the remaining Spirit Cave fauna is only a fraction of the original whole assemblage. We do not know where the lost specimens are located or if they were saved from the original excavation and analysis. Rather than characterize the components of this collection by simply saying "bones are missing," we employ several metrics concerning bone fragmentation and assemblage sample size to understand how the remaining Spirit Cave assemblage may be biased (Cannon 2013; Lyman 1994, 2008). Because the entire excavated collection was not available for study, these metrics necessarily only provide partial insight into the analytical issues surrounding the assemblage.

Fragmentation deals with the breakage of bones and the representation of skeletal elements per specimen (Cannon 2013; Lyman 2008:250). We measured the ratio of NRSP (total Number of Specimens)/NISP between layers at Spirit Cave (Cannon 2013; Conrad et al. 2015; Grayson 1991; Wolverton 2002; Wolverton et al. 2008). This ratio provides an empirical value of fragmentation within assemblages (Cannon 2013). If this ratio is similar across each layer at Spirit Cave, it suggests that fragmentation is occurring equally throughout all stratigraphic layers and is not biasing the assemblage. We expect an assemblage biased by fragmentation to demonstrate greater variability in NRSP/NISP ratios.

Sample size is an important component of faunal assemblages because it provides information on the abundance of remains analyzed (Cannon 1999, 2001; Grayson 1981; Lyman 2008:142). Sample size can be affected by recovery technique, but dry screening through $1 \mathrm{~mm}$ mesh presumably offsets this concern at Spirit Cave (Gorman 1971b:70). In this analysis, we use sample size to understand any limitations present in the remaining portion of the Spirit Cave assemblage. For example, does different sample sizes amongst the layers at Spirit Cave suggest that issues aside from prehistoric human activity impact the collections?

To measure sample size bias, we calculate a Generalized Linear Model (GLM) between both NISP and NTAXA (taxonomic abundance) and MNI and NTAXA per layer. Although previous work has used log-transformed NISP values to make the data conform to the assumptions of linear models (Grayson and Delpech 1998; Lyman 2008:149-152), recent simulation studies show that transformed data performs poorly with high bias (O’Hara and Kotze 2010). Instead, we use generalized linear models because they provide statistical procedures designed to deal with counts. While traditional linear models assume that data points come from a normal distribution, GLM extends this by allowing non-normal error distributions (Bolker 2008:406410). We used Poisson errors and a log-link function because these are widely recognized as good models for count data (Cameron and Trivedi 1998; Zeileis et al. 2007). If a significant (at 95\%) relationship is present in the models, it suggests that sample size biases occur equally throughout the assemblage. A nonsignificant relationship indicates that the biases that are present between layers have no relationship from one layer to the next.

Analysis of Cook's distance and leverage enables us to infer potential issues with sample size (Chatterjee and Hadi 1986). Cook's distance identifies which samples have 
the greatest influence in a regression analysis; leverage examines which samples are the furthest from predicted values. Lastly, we use chi-square to test for differences in taxonomic composition between layers at Spirit Cave based on NISP. We expect no significant difference in the chi-square analysis if subsistence strategies remain the same at Spirit Cave throughout each layer. Our goal with these tests is to identify how comparable the remaining Spirit Cave faunal assemblage is to the originally excavated material from 1966.

\section{RESULTS}

Reanalysis identified a total of 2404 specimens comprising 55 taxa with a total mass of $458.13 \mathrm{~g}$ (Table 4). Several new species were identified, including freshwater crabs (Indochinamon sp.), intermediate and bicolored roundleaf bats (Hipposideros larvatus and bicolor), Burmese hare (Lepus cf. peguensis), Phasianidae (potentially Gallus gallus), elongated tortoise (Indotestudo elongata), black marsh turtle (Siebenrockiella crassicollis), and a single human individual (Homo sapiens). The fossil Crinoid represents a palaeontological specimen in this collection, likely eroded from the cave walls. Animals absent from this assemblage but represented in earlier analyses include wild bovids (Bovinae), langurs (Presbytis sp.), hog badger (Arctonyx collaris), marten (Martes flavigula), bamboo rats (Cannomys/Rhyzomys sp.), and carp (Acrossocheilus sp.). These differences are likely due to the incompleteness of the reanalyzed faunal assemblage.

\section{Bone Fragmentation and Sample Size}

Fragmentation ratios (NRSP/NISP) increase per stratigraphic layer at Spirit Cave (Table 5). This suggests deeper stratigraphic units include fewer identifiable specimens than more recent layers. Interestingly, these ratios are not driven by sample size $\left(r_{s}=0.9, p=0.35\right)$. Bones from Layer 4 arrived without prior organization and aggregation into specimen groups (i.e., bags and boxes), thus the high ratio of fragmentation is unsurprising. These ratios suggest that bone fragmentation does not severely impact the remaining Spirit Cave collection; if it did then NRSP/NISP ratios should be ranked with sample size. More generally, this means that while some layers from Spirit Cave do not have their entire original collection of bones preserved, each layer still has a relatively equal proportion of identifiable specimens.

Generalized linear models suggest that sample size bias is occurring at the site, based on the relationship between NISP and NTAXA $\left(t=0.158, r^{2}=0.820\right.$, $p=0.001)$. There is a significant relationship between MNI and NTAXA $(t=0.21$, $r^{2}=0.926, p=0.006$ ), suggesting that as sample size increases, MNI also increases (see plots in Conrad 2015b). However, NTAXA is not significantly driven by sample size effects within the assemblage $\left(r_{s}=0.70, p=0.23\right)$. Analysis of Cook's distance and leverage indicates that Layer 4 (value \#5 in Fig. 6) is influencing the regression relationship and is furthest from the predicted values. Given that Layer 4 is the most fragmented and has the most unidentifiable specimens of all the layers, bones from Layer 4 most closely represent the original sample excavated from Spirit Cave. Finally, chi-square statistics show that every subsequent layer at Spirit Cave is significantly different (Table 5). Since sample size biases are present, these patterns are likely not driven by forager subsistence strategies. Clearly, bone fragmentation and sample size affect the Spirit Cave faunal assemblage to some degree. 
Table 4. NisP Values per Stratigraphic Layer at Spirit Cave Based on the Results OF THIS ANALYSIS

\begin{tabular}{|c|c|c|c|c|c|c|}
\hline TAXONOMIC CLASSIFICATION & COMMON NAME & LAYER I & LAYER 2 & LAYER 2A & LAYER 3 & LAYER 4 \\
\hline Arthropoda & Insect & & & & & 2 \\
\hline Indochinamon sp. & Freshwater crab & 10 & 21 & 2 & & 3 \\
\hline Bivalvia & Bivalve & & & & & 1 \\
\hline Margaritifera laosensis & Freshwater bivalve & & & 2 & & 2 \\
\hline Gastropoda & Gastropod & & & 9 & & 22 \\
\hline Cyclophorus sp. & $\begin{array}{l}\text { Operculated land } \\
\text { snail }\end{array}$ & & & & 1 & 7 \\
\hline Chiroptera & Bats & & 104 & 7 & 1 & 189 \\
\hline Hipposideros bicolor & $\begin{array}{l}\text { Bicolored roundleaf } \\
\text { bat }\end{array}$ & & & & & 1 \\
\hline Hipposideros larvatus & $\begin{array}{l}\text { Intermediate } \\
\text { roundleaf bat }\end{array}$ & & 14 & & & 5 \\
\hline Hipposideros sp. & Roundleaf bat & & 23 & 8 & & 56 \\
\hline Sus sp. & Wild boar & & 4 & 1 & 2 & 1 \\
\hline Muntiacus sp. & Muntjac deer & & 2 & & 1 & 10 \\
\hline Axis porcinus & Hog deer & & 3 & & & \\
\hline Rusa unicolor & Sambar deer & & 1 & 1 & & 4 \\
\hline Rodentia & Rodents & & 4 & 2 & 2 & 7 \\
\hline Sciuridae & Squirrels & 3 & 2 & & & 1 \\
\hline Ratufa sp. & Giant squirrel & & 1 & & & \\
\hline Muridae & Rats and mice & & & & 1 & 21 \\
\hline Lepus cf. peguensis & Burmese hare & & 1 & & & \\
\hline Carnivora & Carnivores & & 1 & & 4 & 2 \\
\hline Lutra sp. & River otter & & & & 2 & \\
\hline Viverridae & Civets & & 2 & & & \\
\hline Arctictis binturong & Binturong & & & & 1 & \\
\hline Canidae & Jackal/dhole & & & & 2 & 1 \\
\hline Hystricidae cf. & Porcupine & & 1 & & 1 & \\
\hline Felidae & Leopard/tiger/cat & & 2 & & & 3 \\
\hline Felis sp. & Cat & & 1 & & & \\
\hline Primate & Primates & & & & & 2 \\
\hline Homo sapiens & Human & & 1 & & & \\
\hline Hylobates lar & Lar gibbon & & 4 & & 1 & \\
\hline Macaca sp. & Macaque & & 2 & & 2 & 2 \\
\hline Macaca cf. sp. & Macaque & & 4 & & & \\
\hline Nycticebus sp. & Slow loris & & 4 & & 2 & \\
\hline Mammalia, small & Small mammal & 2 & 3 & 5 & 2 & 44 \\
\hline Mammalia, medium & Medium mammal & & 6 & 1 & 6 & 125 \\
\hline Mammalia, large & Large mammal & & & & 2 & 131 \\
\hline Mammalia, indeterminate & Mammal & & & 54 & & \\
\hline Avian & Birds & 1 & & & & \\
\hline Passeriformes & Passerine & 2 & & & 1 & \\
\hline Phasianidae & Phasianid & & & & & 1 \\
\hline
\end{tabular}

(Continued) 
TABLE 4 (Continued)

\begin{tabular}{|c|c|c|c|c|c|c|}
\hline TAXONOMIC CLASSIFICATION & COMMON NAME & LAYER I & LAYER 2 & LAYER 2 A & LAYER 3 & LAYER 4 \\
\hline Reptilia & Reptiles & & & & 1 & 8 \\
\hline Geoemydidae & Hard-shelled turtles & 1 & 1 & & 1 & 14 \\
\hline Siebenrockiella crassicollis & Black marsh turtle & 1 & & & & \\
\hline Testudinidae & Tortoise & & & & 1 & 2 \\
\hline Indotestudo elongata & Elongated tortoise & 4 & & & & 4 \\
\hline Varanus sp. & Monitor lizard & & 2 & & & 1 \\
\hline Serpentes & Snakes & & 1 & & & 2 \\
\hline Pythonidae & Pythons & & & & & 1 \\
\hline Anura & Frogs & & 1 & & & 7 \\
\hline Anura cf. & Frogs & & & & & 8 \\
\hline Cyprinidae & Barbs and carps & 10 & 51 & 8 & & 3 \\
\hline Vertebrate, small/medium & $\begin{array}{l}\text { Small/medium } \\
\text { vertebrate }\end{array}$ & & & & & 1073 \\
\hline Vertebrate & Vertebrate & & 43 & & 70 & \\
\hline Indeterminate & Indeterminate & 10 & 63 & 13 & & \\
\hline Crinoidea & Fossil crinoid & & & & & 1 \\
\hline NRSP $\Sigma$ & & 44 & 373 & 113 & 107 & 1767 \\
\hline
\end{tabular}

Horizontal lines represent divisions between major classes of animals.

Table 5. Fragmentation, Sample Size, and Chi-square Metrics for the Spirit Cave Faunal Assemblage

\begin{tabular}{lcc}
\hline LAYER & NRSP/NISP & CHI-SQUARE \\
\hline 1 & 1.38 & $\chi^{2}=134.076, p<.0001$ \\
2 & 1.45 & $\chi^{2}=275.845, p<.0001$ \\
$2 \mathrm{a}$ & 2.83 & $\chi^{2}=200.676, p<.0001$ \\
3 & 3.96 & $\chi^{2}=1482.152, p<.0001$ \\
4 & 4.49 & \\
\hline
\end{tabular}

\section{Diversity in Fauna and Subsistence}

The ratio of burned specimens to total NISP in the assemblage fluctuates between 11 percent and 28 percent in all layers. These frequencies are clearly related to sample size $\left(r_{s}=0.9, p=0.08\right)$ (Table 6). A right rib specimen of a single Sambar deer (Rusa unicolor) (Layer 2a-SC-00078) (Fig. 7) and a small mammal femur (Layer 4-SC-00191) exhibit cut marks. Gnawing is present on two small mammal long bone specimens (Layer 4-SC-00192/193) (Fig. 8). Overall, cut and gnawed samples comprise less than 1 percent of the assemblage. The taxonomic diversity is relatively rich and includes freshwater bivalves (Margaritifera laosensis), terrestrial land snails $(C y$ clophorus sp.), wild boar (Sus sp.), deer (Muntiacus/Axis/Rusa), and primates (Nycticebus/ 


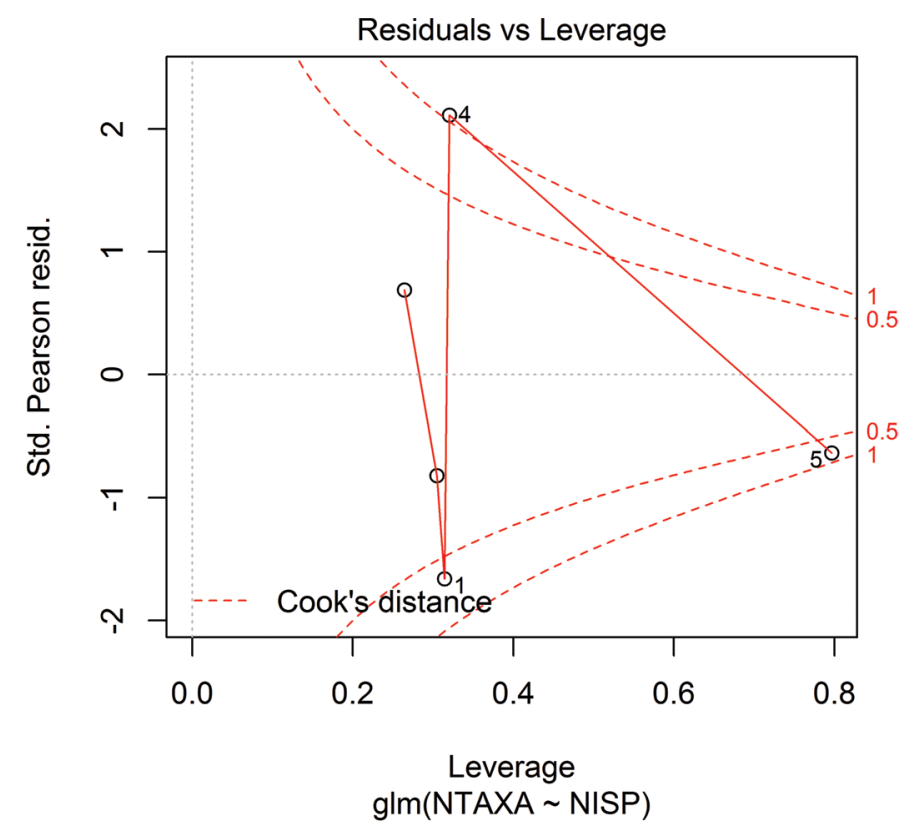

Fig. 6. Cook's distance and leverage based on NISP values. Higher Cook's distance values indicate more influence on the regression relationship; leverage indicates which observations occur furthest from the predicted values. Layer 4 (point \#5) has a high value because it closely represents the original excavated material.

Macaca/Hylobates), among others (Table 4), but due to sample size biases it is unclear how representative these species are of their originally excavated abundances.

Both intermediate and bicolored roundleaf bats (Hipposideros larvatus and bicolor) occur at Spirit Cave. Intermediate roundleaf bats are more common (NISP =19) than bicolored bats (NISP $=1$ ); the genus Hipposideros sp. (NISP $=87$ ) and the order Chiroptera (NISP $=301)$ are also highly abundant. Typically, these specimens consist of long bone shafts; they are extremely difficult to identify below the order level. However, the size and morphology of long bone fragments suggest that all Chiroptera specimens at Spirit Cave are likely from small insectivorous bats (Stimpson 2012). Burnt bat bones comprise a very small proportion of the total NISP (5\% or 19/408) and cut marks are not present on any bat bones, suggesting that natural processes drive bat accumulation at the site. The proportion of bats in the assemblage is remarkably high when they appear. Layer 1 does not have any bats present, but they represent 55 percent (141/257) of NISP values in Layer 2, 38 percent (15/40) in Layer 2a, 4 percent $(1 / 27)$ in Layer 3, and 64 percent $(251 / 393)$ in Layer 4 . The abundance of bats in Layers 2, 2a, and 4 present important considerations for trends in site occupation during the Pleistocene-Holocene transition.

Several new species identifications also provide insights into palaeoecology and subsistence practices at Spirit Cave. Of the small assemblage of birds at the site, a Phasianidae specimen falls into the size range of red junglefowl (Fig. 9). Red junglefowl appeared during the late Pleistocene and is likely the original species of domestic chicken in Southeast Asia (Liu et al. 2006; Miao et al. 2013; Peters et al. 2015; Riztyan et al. 2014; Thompson et al. 2014; Xiang et al. 2014). Elongated tortoise is 
Table 6. Burning (Charred/Calcined/Both) on the Spirit Cave Faunal Remains

\begin{tabular}{|c|c|c|c|c|c|c|}
\hline TAXONOMIC CLASSIFICATION & COMMON NAME & LAYER I & LAYER 2 & LAYER $2 \mathrm{~A}$ & LAYER 3 & LAYER 4 \\
\hline Indochinamon sp. & Freshwater crab & $3 / 0 / 0$ & $6 / 0 / 0$ & $2 / 0 / 0$ & & \\
\hline Cyclophorus sp. & Operculated land snail & & & & & $0 / 3 / 0$ \\
\hline Chiroptera & Bats & & $0 / 7 / 0$ & & & $6 / 0 / 0$ \\
\hline Hipposideros sp. & Roundleaf bat & & $4 / 0 / 0$ & $1 / 0 / 0$ & & $1 / 0 / 0$ \\
\hline Sus sp. & Wild boar & & $0 / 1 / 1$ & $1 / 0 / 0$ & & \\
\hline Muntiacus sp. & Muntjac deer & & & & $1 / 0 / 0$ & $2 / 0 / 1$ \\
\hline Axis porcinus & Hog deer & & $1 / 0 / 0$ & & & \\
\hline Rusa unicolor & Sambar deer & & & $1 / 0 / 0$ & & \\
\hline Rodentia & Rodents & & & $1 / 0 / 0$ & $0 / 1 / 0$ & $1 / 0 / 0$ \\
\hline Sciuridae & Squirrels & $2 / 0 / 1$ & $0 / 1 / 0$ & & & \\
\hline Ratufa sp. & Giant squirrel & & $1 / 0 / 0$ & & & \\
\hline Muridae & Rats and mice & & & & & 0/0/1 \\
\hline Lepus cf. peguensis & Burmese hare & & $0 / 1 / 0$ & & & \\
\hline Canidae & Jackal/dhole & & & & $1 / 0 / 0$ & 0/0/1 \\
\hline Viverridae & Civets & & $1 / 0 / 1$ & & & \\
\hline Arctictis binturong & Binturong & & $1 / 0 / 0$ & & & \\
\hline Hystricidae cf. & Porcupine & & $0 / 1 / 0$ & & $0 / 0 / 1$ & \\
\hline Felis sp. & Cat & & $2 / 0 / 0$ & & & \\
\hline Primate & Primates & & & & & $1 / 0 / 0$ \\
\hline Hylobates lar & Lar gibbon & & $0 / 1 / 0$ & & $0 / 0 / 1$ & \\
\hline Macaca sp. & Macaque & & $1 / 0 / 0$ & & & $1 / 0 / 0$ \\
\hline Macaca cf. sp. & Macaque & & $1 / 1 / 0$ & & & \\
\hline Nycticebus sp. & Slow loris & & $0 / 1 / 0$ & & $0 / 1 / 0$ & \\
\hline Mammalia, small & Small mammal & $2 / 0 / 0$ & & $0 / 0 / 3$ & $0 / 0 / 2$ & $5 / 7 / 0$ \\
\hline Mammalia, medium & Medium mammal & & $2 / 1 / 0$ & & $0 / 0 / 2$ & $10 / 4 / 1$ \\
\hline Mammalia, large & Large mammal & & & & $2 / 0 / 0$ & $32 / 13 / 0$ \\
\hline Mammalia, indeterminate & Mammal & & & $4 / 3 / 0$ & & \\
\hline Avian & Birds & $1 / 0 / 0$ & & & & \\
\hline Geoemydidae & Hard-shelled turtles & & $0 / 1 / 0$ & & $0 / 1 / 0$ & $3 / 0 / 0$ \\
\hline Varanus sp. & Monitor lizard & & & & & $0 / 1 / 0$ \\
\hline Anura & Frogs & & & & & $0 / 2 / 0$ \\
\hline Cyprinidae & Barbs and carps & & $4 / 0 / 0$ & & & \\
\hline Vertebrate, small/medium & $\begin{array}{l}\text { Small/medium } \\
\text { vertebrate }\end{array}$ & & & & & $69 / 29 / 0$ \\
\hline Vertebrate & Vertebrate & & $4 / 22 / 2$ & & $0 / 3 / 14$ & \\
\hline Indeterminate & Indeterminate & & $2 / 0 / 0$ & & & \\
\hline$\Sigma$ & & $8 / 0 / 1$ & $30 / 38 / 4$ & $10 / 3 / 3$ & $4 / 6 / 20$ & $131 / 59 / 4$ \\
\hline Summed Total & & 9 & 72 & 16 & 30 & 194 \\
\hline
\end{tabular}

present in Layers 4 and 1, while the black marsh turtle only occurs in Layer 1. A single, entirely calcined, Burmese hare specimen is present in Layer 2.

\section{DISCUSSION}

Although a diverse suite of fauna was identified in this reanalysis, the incompleteness of the assemblage prohibits complete analysis of diet breadth throughout the 


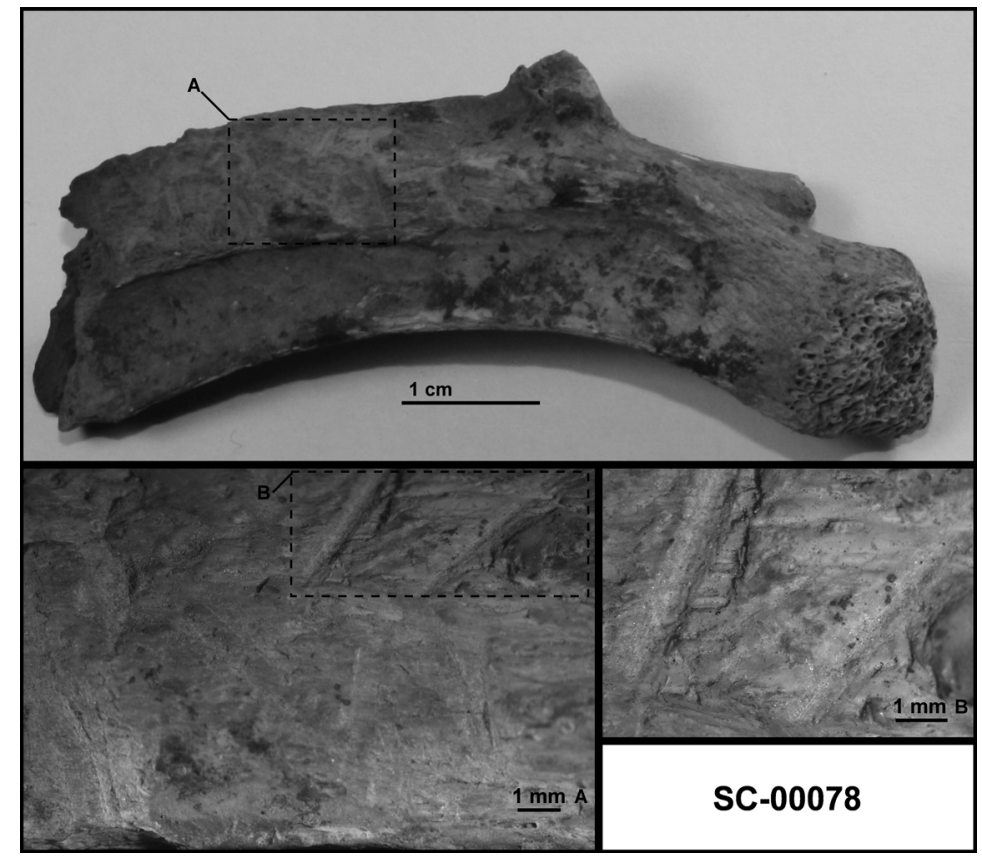

Fig. 7. Cut marks present on a right rib of a Sambar deer (Rusa unicolor) (Layer 2a-SC-00078). Image A taken at $1 \mathrm{x}$ magnification on a Nikon SMZ1500 stereomicroscope attached to a SPOT Insight FireWire digital camera; close-up image B taken at 2x. Macro-photograph courtesy of Hannah G. Van Vlack.

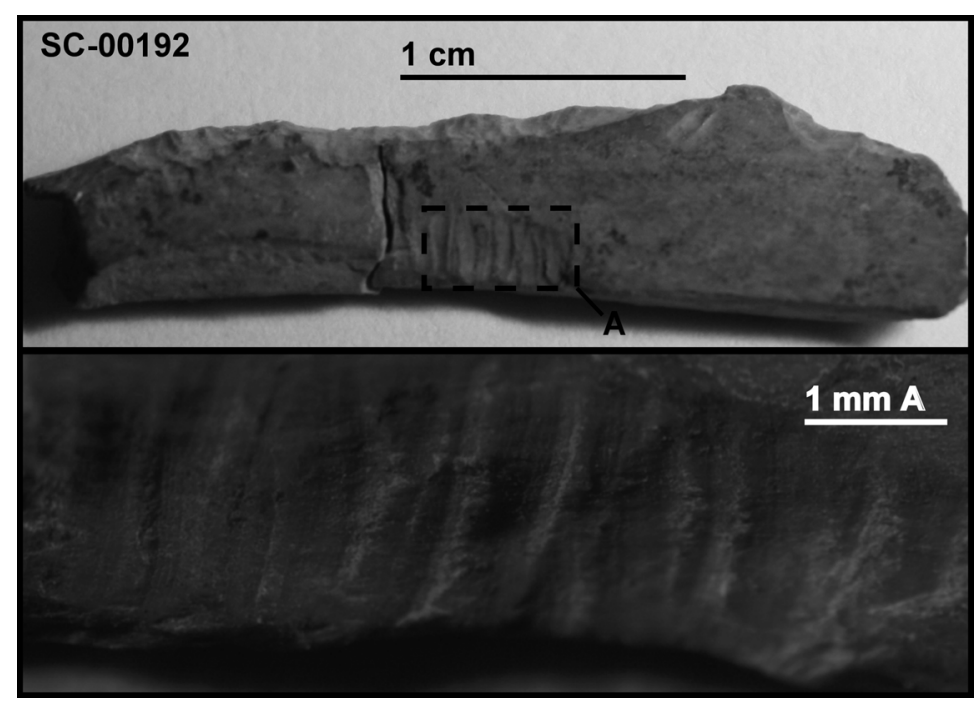

Fig. 8. Gnawing by an unidentified rodent on a small mammal long bone (Layer 4-SC-00192). Image A taken at $1.5 \mathrm{x}$ magnification on a Nikon SMZ1500 stereomicroscope attached to a SPOT Insight FireWire digital camera. Macro-photograph courtesy of Hannah G. Van Vlack. 


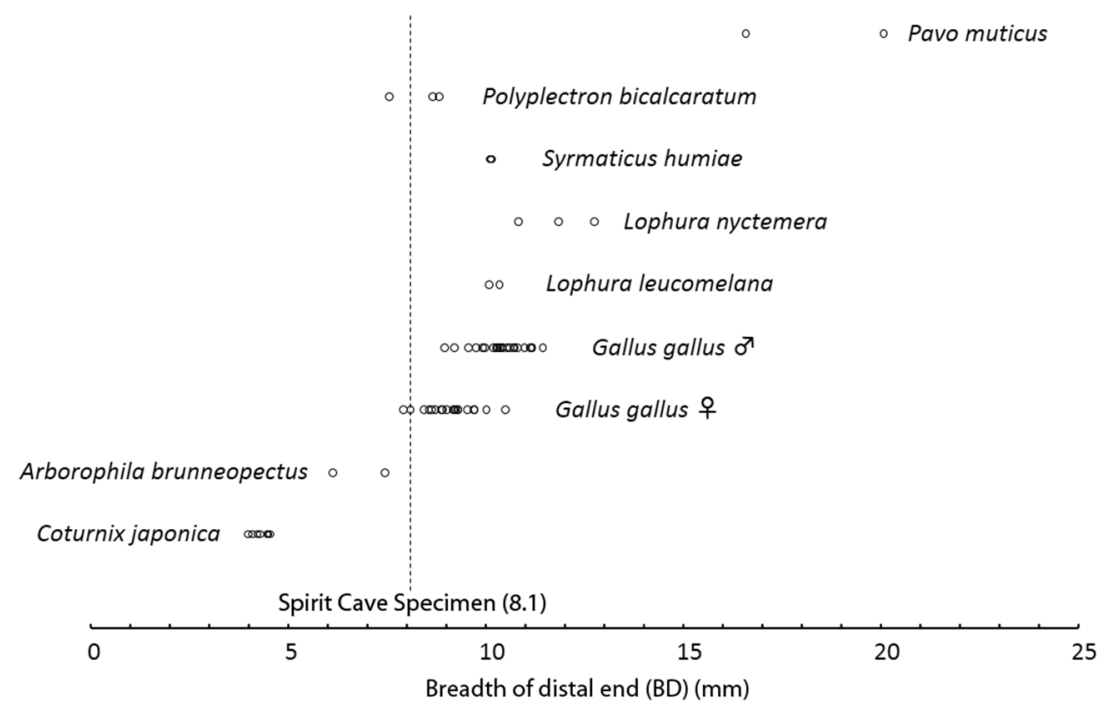

Fig. 9. Comparison of distal breadth widths $(\mathrm{mm})$ for Phasianidae species currently inhabiting Mainland Southeast Asia. Spirit Cave specimen noted with dashed vertical line. Measurements derived from comparative collections at: Institute of Palaeoanatomy, Domestication Research and History of Veterinary Medicine (Germany); Louisiana State University Museum of Natural Science and Smithsonian National Museum of Natural History (USA); Nagoya University Museum, Nara National Research Institute for Cultural Properties, and Yamashina Institute for Ornithology (Japan).

Pleistocene-Holocene transition. ${ }^{6}$ Nevertheless, new species-level identifications provide strong evidence for subsistence strategies and palaeoecological dynamics at Spirit Cave. Both wet-season and dry-season resources were identified in this collection within the same layers. Our discussion focuses on the record of Hipposiderid bats (site occupation), Burmese hare (anthropogenic landscape modification), elongated tortoise and black marsh turtle (palaeoenvironmental change/range contraction), and a Phasianidae bird (early evidence for exploitation). The abundance of bat bones in particular suggests that hunter-gatherer groups occupied Spirit Cave sporadically during the Pleistocene-Holocene transition.

\section{Site Occupation}

Bat identifications allow a reinterpretation of Gorman's hypothesis on the pattern of hunter-gatherer site occupation at Spirit Cave. Gorman argued that hunter-gatherers used the cave relatively continuously during Layers $2,2 \mathrm{a}$, and 4 , that is, during the Pleistocene-Holocene transition. However, the abundance of Hipposiderid bat remains in these layers suggests otherwise. Hipposiderid bats roost in caves, mines, or tunnels in large colonies throughout Southeast Asia (Bates and Harrison 1997:96-97; Francis 2008:218-223; Kingston et al. 2006:90-91, 99-100; Lekagul and McNeely $1988: 161,177$ ). Some H. bicolor roosts have numbers upward of 250 (Lekagul and McNeely 1988:161) or "hundreds of individuals" (Douangboubpha et al. 2010). Although little is known for $H$. larvatus, this species is also described as roosting in "enormous" (Bates and Harrison 1997:96), "huge" (Borissenko and Kruskop 2003: 76), or "large" colonies (Kingston et al. 2006:91). 
Hipposiderid bats do not share roosting localities with humans, however (Hand and Grant-Mackie 2011; Ho and Lee 2003). One study suggests that Formosan leafnosed bats (Hipposideros armiger terasensis) typically occupy roosts (caves) with high ceilings and high ground-surface area covered in water (Ho and Lee 2003), and favor roost locations with low anthropogenic disturbance over sites with more suitable microclimates. Since these bats do not roost when humans are present, their dominance in Spirit Cave during the Pleistocene-Holocene transition suggests human site abandonment.

The presence of bats in these layers does not automatically refute Gorman's hypothesis that humans ate bats, but the lack of any evidence for consumption does. There is a record of bat consumption in Oceania, but the species consumed are typically large flying foxes or megabats (Pteropus sp.) (Hand and Grant-Mackie 2011; Hawkins et al. 2016; Valentin et al. 2010). If prehistoric hunter-gatherers consumed the roundleaf bat species at Spirit Cave there should be primary evidence of this process (e.g., burning, bone breakage, digestive modification, stratigraphic correlation with artifacts, and non-cave roosting ecology). Hipposiderid bat remains at Spirit Cave do not show signs of cut marks, tooth eroding, or bone breakage consistent with human activity (cf. Lyman 1994). The completeness of bat bones at Spirit Cave also suggests they died naturally and accumulated into the faunal assemblage from large roosting groups, rather than being exploited by humans for subsistence.

The abundance of bats and the lack of any evidence of human consumption indicate human occupations in Layers 2 and 4 are not continuous, as Gorman (1970) suggested. Without the complete Spirit Cave faunal assemblage, it is difficult to make definitive statements regarding Hipposiderid bats at the site, especially in relation to broader notions of palaeoenvironmental change and ecology (Stimpson 2012). However, given the known behavior of these bat taxa, their abundance in Layers 2 and 4 suggests humans did not occupy the site while bat bones accumulated. Conversely, the lack of bats in Layers 1 and 3 suggests either a palaeoecological shift or human occupation made habitation at Spirit Cave undesirable for Hipposiderid bats. More ecological research is required before understanding this aspect of the assemblage.

In general, lower levels of site occupation, and thus increased mobility during the Pleistocene-Holocene transition, match regional trends of variability and complexity in hunter-gatherer activities during this period in Mainland and Maritime Southeast Asia (Marwick 2013; Rabett 2012; Rabett and Barker 2010; Shoocongdej 2000, 2006, 2010; White 2011).

\section{Anthropogenic Landscape Disturbance}

Burmese hare only appears once in the Spirit Cave assemblage (Layer 2, 8000 years B.P.). This specimen, a left calcaneus (SC-00107), is entirely calcined, suggesting human activity was the primary accumulation agent. However, targeted human hunting of this taxon is unlikely due to its behavior. The Burmese hare is nocturnal (Francis 2008:379-381; Lekagul and McNeely 1988:333-334), but nighttime hunting is rare in the ethnographic record from this region (Pookajorn 1985, 1992). Similarly, L. peguensis is infrequent in the archaeological record. At Lang Rongrien Rockshelter in southern Thailand, a single specimen dating to the early Holocene ( 7,655 $\pm 70-$ 9,655 \pm 90 years uncal B.P.) is listed as "Hare (?)" (Kijngam 1990:76). The largest assemblage of $L$. peguensis specimens (NISP $=29$ ) comes from the Bronze Age site Ban Chiang in northeast Thailand (Higham and Kijngam 1979; Kijngam 1979: 49-51). 
L. peguensis (NISP $=2$ ) also appears in the Neolithic layers at Ban Non Wat, another site in northeast Thailand (Kijngam 2010:195-197).

Due to its rarity, the role of the Burmese hare in prehistoric subsistence has not been explored in any depth. Its significance for environmental reconstruction, on the other hand, is well known. L. peguensis has a well-documented habitat preference for areas recently cleared of forest by humans or by natural fire events (Duckworth et al. 2008; Francis 2008:379-381; Lekagul and McNeely 1988:333-334). This has important implications for the archaeological record because it means Burmese hare may be a proxy for anthropogenic landscape disturbance. Evidence suggests hunter-gatherers only began to exploit this species after forest clearing became widespread (Higham and Kijngam 1979). At Ban Chiang and Ban Non Wat, the presence of Burmese hare (among other species) has been used to argue for prehistoric landscape clearing and regeneration for rice cultivation (Higham and Kijngam 1979:227-228; Kijngam 1979: 49-51, 2010:195-197).

The presence of a single L. peguensis specimen in the Spirit Cave assemblage is not strong evidence of anthropogenic activities. However, the presence of this taxon does suggest that landscape modification, whether human or natural in origin, increased around 8000 years B.P. in northwest Thailand. Furthermore, although not true domesticates, many of the botanical remains at Spirit Cave indicate the exploitation of local primary and secondary forests (Gorman 1971b; Hutterer 1983, 1988; Yen 1977). This evidence concurs with recent palaeobotanical research arguing that human-environmental modification increased in Southeast Asia at this time (Hunt and Rabett 2014).

\section{Tortoises and Turtle Range Contraction}

Consumption of turtles and tortoises is a fairly common practice in contemporary indigenous groups from Thailand and Peninsular Malaysia (Kuchikura 1996; Pookajorn 1985). It is also indicated in prehistoric zooarchaeological assemblages throughout Southeast Asia (Conrad 2015a; Mudar and Anderson 2007; Pritchard et al. 2009). Excluding marine sea turtles, there is a broad diversity of species present in this region, including Geoemydidae, Platysternidae, Testudinidae, andTrionychidae types (Nutaphand 1979; Thirakhupt and van Dijk 1994; Vetter and van Dijk 2006). The presence of Indotestudo elongata (a.k.a. ground tortoise) at Spirit Cave is in line with patterns found elsewhere in the Thai zooarchaeological record. For example, this taxon is abundant at Steep Cliff Cave (Tham Phaa Can) (Higham 1989:58), Banyan Valley Cave (Tham Sai) (Higham 1977), and Moh Khiew Cave II (Auetrakulvit 2004; Mheetong 2014).

While I. elongata currently occupies the Spirit Cave region, Siebenrockiella crassicollis (black marsh turtle) does not; it only appears in the Mainland Southeast Asian zooarchaeological record at Gua Sagu in Peninsular Malaysia (Rabett 2012:255) (Fig. 1). According to the IUCN Red List of Threatened Species, S. crassicollis currently ranges as far north as northeastern Lampang Province and west to the western edge of Kanchanaburi Province in Thailand (Asian Turtle Trade Working Group 2000) (Fig. 10). This modern distribution is approximately $160 \mathrm{~km}$ to the southeast of Spirit Cave.

The difference between the current $S$. crassicollis distribution and the zooarchaeological record thus suggests a range contraction for this taxon occurred sometime between the mid-Holocene and the present. One possible explanation for this involves climate change. In general, S. crassicollis enjoys wet habitats. Inhabiting slow moving and shallow standing/swamp and marsh water (i.e., ponds, streams, lakes), this 
$2016 \cdot 55(\mathrm{I})$

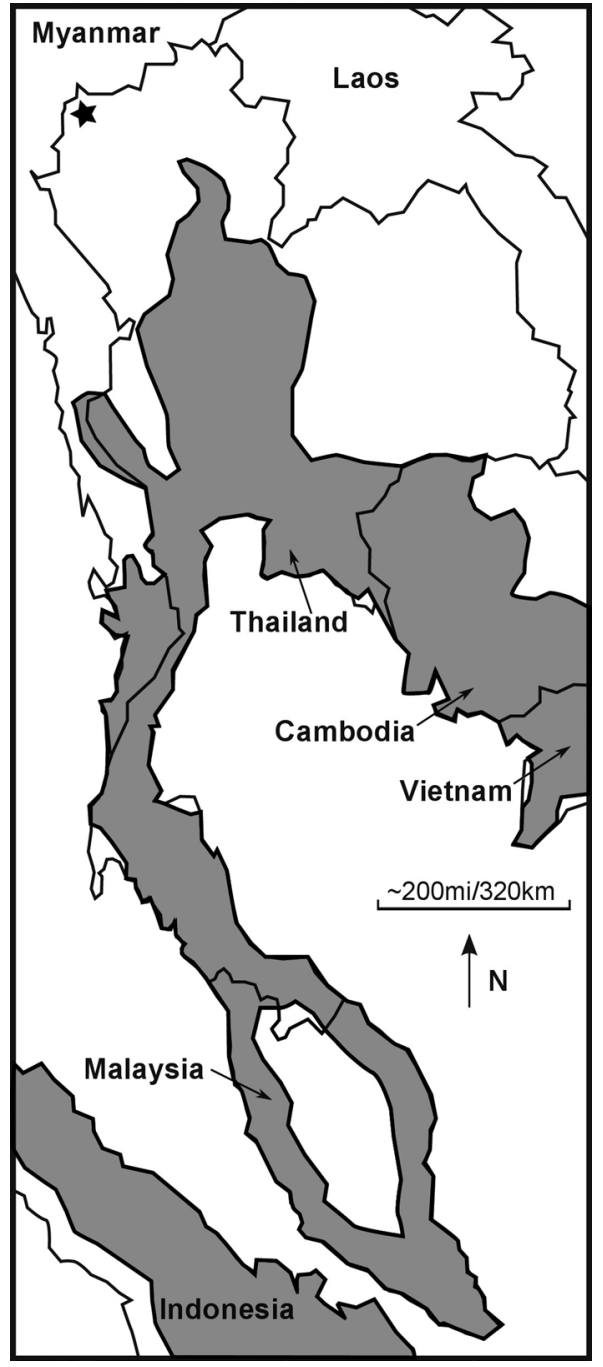

Fig. 10. Modern distribution of the black marsh turtle (Siebenrockiella crassicollis) in Southeast Asia (shaded area). Black star marks location of Spirit Cave. Note $\sim 160 \mathrm{~km}$ contraction in range. Spatial data adapted from Asian Turtle Trade Working Group (2000).

species is distributed widely throughout Southeast Asia (Das 2010:173; Ernst and Barbour 1989:187-188; Taylor 1970:125). Its presence here suggests that environments near Spirit Cave were wetter around 7000 years B.P. Palaeoenvironmental proxy data from oxygen isotope sequences in freshwater bivalves support this hypothesis (Marwick and Gagan 2011). Furthermore, palynological evidence suggests a decrease in precipitation in Thailand around 5000 years ago (White et al. 2004). Without additional data, however, it is impossible to rule out anthropogenic hunting as a possible driver for the range contraction.

\section{Late Pleistocene Phasianidae Exploitation}

Importance of the late Pleistocene Phasiandiae specimen from Spirit Cave lies in its early date and possible identification as a red junglefowl (?Gallus gallus). Bones of Gallus sp. have been reported in several sites from Thailand and Peninsular Malaysia 
(Conrad 2015a), including Ment Cave (Pookajorn 1988: 158), Lang Rongrien Rockshelter (Kijngam 1990:76), and Moh Khiew Cave II (Auetrakulvit 2004:330); however, our knowledge of Phasianidae and avian exploitation in general remains low. An exception to this comes from the Niah Caves in Island Southeast Asia where evidence for avian exploitation (including Phasianids) during the past 45,000 years is extensive (Barton et al. 2013; Piper and Rabett 2014; Stimpson 2009).

The Spirit Cave tibiotarsus shows similarity in distal breadth width (Driesch 1976) to female red junglefowl, but it also shares size characteristics with the Chinese francolin (Francolinus pintadeanus), bar-backed partridge (Arborophila brunneopectus) and grey peacock-pheasant (Polyplectron bicalcaratum) (Fig. 9). All of these taxa currently inhabit the region surrounding Spirit Cave (Robson 2008).

If future analyses do support a Gallus gallus identification for this Spirit Cave specimen, then it will join a suite of evidence for possibly early red junglefowl exploitation in Mainland Southeast Asia (Fumihito et al. 1994; Liu et al. 2006; Miao et al. 2013; Riztyan et al. 2014). Continued analysis of the Spirit Cave Phasianid specimen is clearly warranted.

\section{CONCLUSION}

Reanalysis of the Spirit Cave fauna provides several new insights into forager adaptations during the Pleistocene-Holocene transition in Mainland Southeast Asia. While the assemblage is incomplete and does not represent the full collection excavated by Gorman, some interesting findings are nevertheless present. Bat presence during the Pleistocene-Holocene transition indicates a sparse forager occupation sequence. Furthermore, the presence of Burmese hare suggests localized forest disturbance during the early Holocene. Black marsh turtle indicates a mid- to late Holocene range contraction for this species and potentially wetter environments near Spirit Cave. Finally, the late Pleistocene Phasianidae specimen indicates early exploitation of birds in this region of Mainland Southeast Asia.

Our interpretations also generate some new questions. For example, how did palaeoenvironmental change affect faunal turnover during the Pleistocene-Holocene transition? How does the presence of late Pleistocene Phasianidae exploitation at Spirit Cave fit into broader patterns of avian exploitation processes throughout Southeast Asia? Shifting range distribution of the black marsh turtle and the possible presence of red junglefowl indicate that these are fruitful questions for future analyses.

Although our interpretations are necessarily broad because the Spirit Cave faunal collection is only a portion of the original assemblage, our reanalysis provides new evidence of hunter-gatherer adaptations during the past $12,000-7000$ years. The palaeoecological, subsistence, and hunter-gatherer occupation data established in this reanalysis renews the importance of Spirit Cave in Southeast Asian prehistory.

\section{ACKNOWLEDGMENTS}

Thank you Rachanie Thosarat and Peter $\mathrm{Ng}$ for providing fish and crab analyses during this project. Also, our gratitude is extended to Hannah G. Van Vlack for providing photographs of specimens and to Sherry V. Nelson for providing access to her stereomicroscope. We appreciate the assistance with lithic identifications provided by Bruce Huckell. Thank you to Cholawit Thongcharoenchaikit and Somchai Bussarawit for providing access to Chelonian comparatives. Also, we are grateful for access to Avian comparatives at the Institute of Palaeoanatomy, Domestication Research and History of 
Veterinary Medicine (Germany), the Louisiana State University Museum of Natural Science (USA), Nagoya University Museum (Japan), Nara National Research Institute for Cultural Properties (Japan), Smithsonian National Museum of Natural History (USA), and Yamashina Institute for Ornithology (Japan). Finally, we are sincerely grateful to Emily L. Jones, Lawrence G. Straus, students in the Spring 2015 ANTH 570 course at UNM, and two anonymous reviewers for providing invaluable comments on this manuscript.

\section{NOTES}

1. Gorman (1971b:65-67) referred to Spirit Cave as "Tham Phili Maen," but this is a misspelling. The correct spelling of Spirit Cave in Thai is Tham Phii Man. Thank you to Rasmi Shoocongdej for providing the accurate spelling.

2. This was the only chamber Gorman excavated.

3. Rolf A. M. Brandt identified invertebrates as presence $(+) /$ absence $(-)$ and Charles Higham identified all vertebrates as MNI (Brandt 1971b:137; Higham 1971b:133-136). Brandt identified invertebrates to a finer stratigraphic division than Higham. As such, no vertebrate counts occur in Layers 1a, 2a, or 3a.

4. Chester Gorman asked Charles Higham if he would analyze the faunal assemblage from Spirit Cave in 1968. The material was airmailed from Hawai'i to the University of Otago where Higham identified the specimens as best he could without a comparative collection available.

5. No material from Gorman's second season of excavation at Spirit Cave in 1971 was analyzed in this study (see White 2004).

6. So few botanical remains were pulled from the faunal assemblage that we did not test for evidence of plant cultivation origins (Conrad 2015b).

\section{REFERENCES CITED}

Asian Turtle Trade Working Group

2000 Siebenrockiella crassicollis. The IUCN Red List of Threatened Species 2014-3: e.T39616A10251374. http://www.iucnredlist.org/details/39616/0. Accessed 3 March 2015.

Auetrakulvit, Prasit

2004 Faunes du Pléistocène final à l'Holocéne de Thaïlande: approche archéozoologique. Ph.D. diss. Université Aix-Marseille I.

Barton, Huw, Graeme Barker, David Gilbertson, Chris Hunt, Lisa Kealhofer, Helen Lewis, Victor Paz, Philip J. Piper, Ryan J. Rabett, Tim Reynolds, and Katherine Szabó

2013 Late Pleistocene foragers, c. 35,000-11,500 years ago, in Rainforest Foraging and Farming in Island Southeast Asia: The Archaeology of the Niah Caves, Sarawak, vol. I: 173-216, ed. G. Barker. Cambridge: McDonald Institute for Archaeological Research.

Bates, Paul J. J., and David L. Harrison

1997 Bats of the Indian Subcontinent. Kent: Harrison Zoological Museum.

BOLKer, B. M.

2008 Ecological Models and Data in R. Princeton: Princeton University Press.

Borissenko, Alex V., and Sergei V. Kruskop

2003 Bats of Vietnam and Adjacent Territories: An Identification Manual. Biodiversity of Vietnam Series. Moscow and Hanoi: Joint Russian-Vietnamese Science and Technological Tropical Centre.

BRANDT, ROLF A. M.

1971 Appendix II: Mollusks from Spirit Cave, North Thailand, in Prehistoric Research in Northern Thailand: A Cultural-Chronographic Sequence from the Late Pleistocene through to the Early Recent Period: 137. Ph.D. diss. by Chester F. Gorman, University of Hawai'i.

1974 The non-marine aquatic Mollusca of Thailand. Archiv für Molluskenkunde 105(I-IV) :1-423.

Cameron, A. Colin, and Pravin K. Trivedi

1998 Regression Analysis of Count Data. New York: Cambridge University Press.

Cannon, Michael D.

1999 A mathematical model of the effects of screen size on zooarchaeological relative abundance measures. Journal of Archaeological Science 26:205-214.

2001 Archaeofaunal relative abundance, sample size, and statistical methods. Journal of Archaeological Science 28: 185-195. 
2013 NISP, bone fragmentation, and the measurement of taxonomic abundance. Journal of Archaeological Method and Theory 20:397-419.

Chatterjee, Samprit, and Ali S. Hadi

1986 Influential observations, high leverage points, and outliers in linear regression. Statistical Science $1(3): 379-416$.

Conrad, Cyler

2015a Archaeozoology in Mainland Southeast Asia: Changing methodology and Pleistocene to Holocene forager subsistence patterns in Thailand and Peninsular Malaysia. Open Quaternary $1(7): 1-23$.

$2015 b$ Archaeological Databases for Spirit Cave, Mae Hong Son Province, Thailand [dataset]. University of New Mexico. http://hdl.handle.net/1928/26730.

Conrad, Cyler, Kenneth W. Gobalet, Kale Bruner, and Allen G. Pastron

2015 Hide, tallow and terrapin: Gold rush-era zooarchaeology at Thompson's Cove (CA-SFR186H), San Francisco, California. International Journal of Historical Archaeology 19(3) :502-551.

DAS, INDRANEIL

2010 A Field Guide to the Reptiles of South-East Asia. London: New Holland Publishers.

Douangboubpha, Bounsavane, Sara Bumrungsri, Pipat Soisook, Susan W. Murray, Sébastien

J. Puechmaille, Chutamas Satasook, Si Si Hla Bu, David L. Harrison, and Paul J. J. Bates

2010 A taxonomic review of Hipposideros halophyllus, with additional information on $H$. ater and H. cineraceus (Chiroptera: Hipposideridae) from Thailand and Myanmar. Acta Chiropterologica $12(1): 29-50$.

DRIESCH, A.

1976 A guide to the measurement of animal bones from archaeological sites. Peabody Museum Bulletin 1:1-136.

Duckworth, J. W., R. Steinmetz, and A. Pattanavibool

2008 Lepus peguensis. The IUCN Red List of Threatened Species, Version 2014-3: e.T41284A10433206. http://dx.doi.org/10.2305/IUCN.UK.2008.RLTS.T41284A10433206. en. Accessed 27 February 2015.

Ernst, Carl H., and Roger W. Barbour

1989 Turtles of the World. Washington DC: Smithsonian Institution Press.

FLANNERY, Kent V.

1973 The origins of agriculture. Annual Review of Anthropology 2:271-310.

Francis, Charles M.

2008 A Field Guide to the Mammals of Thailand and South-East Asia. Bangkok: Asia Books.

Fuminito, Akishinonomiya, Tetsuo Miyake, Shin-ichiro Sumi, Masaru Takada, Susumu Ohno, AND MORIO KONDO

1994 One subspecies of the red junglefowl (Gallus gallus gallus) suffices as the matriarchic ancestor of all domestic breeds. Proceedings of the National Academy of Sciences $91: 12505-12509$.

Glover, I. C.

1977 The Hoabinhian: Hunter-gatherers or early agriculturalists in South-East Asia?, in Hunters, Gatherers, and First Farmers Beyond Europe: 145-166, J.V.S. Megaw. Leicester: Leicester University Press.

Gorman, Chester F.

1969 Hoabinhian: A pebble-tool complex with early plant associations in Southeast Asia. Science 163(3868): 671-673.

1970 Excavations at Spirit Cave, North Thailand: Some interim interpretations. Asian Perspectives 13:79-107.

$1971 a$ The Hoabinhian and after: Subsistence patterns in Southeast Asia during the late Pleistocene and early recent periods. World Archaeology 2(3):300-320.

$1971 b$ Prehistoric Research in Northern Thailand: A Cultural-Chronographic Sequence from the Late Pleistocene through to the Early Recent Period. Ph.D. diss. University of Hawai'i.

Grayson, Donald K.

1981 The effects of sample size on some derived measures in vertebrate faunal analysis. Journal of Archaeological Science 8:77-88.

1984 Quantitative Zooarchaeology. Orlando: Academic Press.

1991 Alpine faunas from the White Mountains, California: Adaptive change in the late Prehistoric Great Basin? Journal of Archaeological Science 18: 483-506. 
Grayson, Donald K., and Françoise Delpech

1998 Changing diet breadth in the Early Upper Palaeolithic of southwestern France. Journal of Archaeological Science 25:1119-1129.

Hand, Suzanne J., and Jack A. Grant-Mackie

2011 Late-Holocene bats of Mé Auré Cave, New Caledonia: Evidence of human consumption and a new species record from the recent past. The Holocene 22(1): 79-90.

Hawkins, Stuart, Sue O'Connor, and Shimona Kealy

2016 Late Quaternary hominin-bat (Chiroptera) interactions in the Asia-Pacific. Archaeology in Oceania, 19 January. doi: 10.1002/arco.5084.

Higham, Charles

1971 Appendix 1: Spirit Cave: The Faunal Remains, in Prehistoric Research in Northern Thailand: A Cultural-Chronographic Sequence from the Late Pleistocene through to the Early Recent Period: 133-136, Ph.D. dissertation by Chester F. Gorman, University of Hawai'i.

1972 Initial model formulation in terra incognita, in Models in Archaeology: 453-476, ed. David L. Clarke. London: Methuen \& Co. Ltd.

1977 Economic change in Prehistoric Thailand, in Origins of Agriculture: 385-412, ed. Charles A. Reed. Chicago: Mouton Publishers.

1989 The Archaeology of Mainland Southeast Asia: From 10,000 B.C. to the Fall of Angkor. Cambridge: Cambridge University Press.

Higham, Charles, and Amphan Kijngam

1979 Ban Chiang and northeast Thailand; the palaeoenvironment and economy. Journal of Archaeological Science 6:211-233.

Ho, Ying-Yi, AND Ling-Ling LeE

2003 Roost selection by Formosan leaf-nosed bats (Hipposideros armiger terasensis). Zoological Science $20: 1017-1024$

Hunt, C. O., And R. J. Rabett

2014 Holocene landscape intervention and plant food production strategies in island and mainland Southeast Asia. Journal of Archaeological Science $51: 22-33$.

Hutterer, Karl LeOpold

1983 The natural and cultural history of Southeast Asian agriculture: Ecological and evolutionary considerations. Anthropos 78(1/2): 169-212.

1988 The Prehistory of the Asian rain forests, in People of the Tropical Rain Forest: 63-72, ed. J. S. Denslow and C. Padoch. Berkeley: University of California Press.

Jones, Emily L. and Caroline Gabe

2015 The promise and peril of older collections: Meta-analyses and the zooarchaeology of Late Prehistoric/Early Historic New Mexico. Open Quaternary 1:6:1-13.

KiJngAM, AMPHAN

1979 The Faunal Spectrum of Ban Chiang and its Implications for Thai Culture History. M.A. thesis. University of Otago.

1990 Appendix: Identification of Faunal Remains from Stratigraphic Units 5 and 6, Lang Rongrien Rockshelter, Thailand, in Lang Rongrien Rockshelter: A Pleistocene, early Holocene Archaeological Site from Krabi, Southwestern Thailand: 76, ed. Douglas D. Anderson. Philadelphia: University of Pennsylvania Museum Publications.

2010 The mammalian fauna, in The Origins of the Civilization of Angkor, vol. 4, The Excavation of Ban Non Wat, Part Two: The Neolithic Occupation: 195-197, ed. C.F.W. Higham and A. Kijngam. Bangkok: The Fine Arts Department of Thailand.

Kingston, Tigga, Lim Boo Liat, and Zubaid Akbar

2006 Bats of Krau Wildlife Reserve. Bangi: Penerbit Universiti Kebangsaan Malaysia.

KuChiKura, Yukio

1996 Fishing in the tropical rain forest: Utilization of aquatic resources among the Semaq Beri hunter-gatherers of Peninsular Malaysia. Senri Ethnological Studies 42:147-174.

Lampert, C. D., I. C. Glover, R.E.M. Hedges, C. P. Heron, T.F.G. Higham, B. Stern, R. ShooCONGDEJ, AND G. B. ThOMPSON

2003 Dating resin coating on pottery: The Spirit Cave early ceramic dates revised. Antiquity 77(295) : 126-133.

2004 Response to Joyce C. White's Comment on dates from a resin-coated sherd from Spirit Cave, Thailand. Antiquity 78(299): 186-187. 
Lekagul, Boonsong, ANd JefFrey McNeely

1988 Mammals of Thailand. Bangkok: Darnsutha Press.

Liu, Yi-Ping, Gui-Sheng Wu, Yong-Gang Yao, Yong-Wang Miao, Gordon Luikart, Mumtaz Baig, Albano Beja-Pereira, Zhao-Li Ding, Malliya Gounder Palanichamy, and Ya-Ping Zhang 2006 Multiple maternal origins of chickens: Out of the Asian jungles. Molecular Phylogenetics and Evolution 38:12-19.

LyMAN, R. LEE

1994 Vertebrate Taphonomy. Cambridge: Cambridge University Press.

2008 Quantitative Paleozoology. Cambridge: Cambridge University Press.

MARWICK, BEN

2013 Multiple Optima in Hoabinhian flaked stone artefact palaeoeconomics and palaeoecology at two archaeological sites in Northwest Thailand. Journal of Anthropological Archaeology $32: 553-564$.

Marwick, Ben, and Michael K. Gagan

2011 Late Pleistocene monsoon variability in northwest Thailand: An oxygen isotope sequence from the bivalve Margaritanopsis laosensis excavated in Mae Hong Son province. Quaternary Science Reviews 30:3088-3098.

MHeEtong, Supalak

2014 An Analysis of Reptile Bone from an Excavation at Moh-Khiew Cave, Krabi Province. M.A. thesis. Silpakorn University.

Miao, Y.-W., M.-S. Peng, G.-S. Wu, Y.-N. Ouyang, Z.-Y. Yang, N. Yu, J.-P. Liang, G. Pianchou, A. Beja-Pereira, B. Mitra, M. G. Palanichamy, M. Baig, T. K. Chaudhuri, Y.-Y. Shen, Q.-P. Kong, R. W. Murphy, Y.-G. YaO, AND Y.-P. Zhang

2013 Chicken domestication: An updated perspective based on mitochondrial genomes. Heredity $110: 277-282$.

Mudar, Karen, and Douglas Anderson

2007 New evidence for Southeast Asian Pleistocene foraging economies: Faunal remains from the early levels of Lang Rongrien Rockshelter, Krabi, Thailand. Asian Perspectives 46(2) : 298-334.

NuTAPHAND, Wirot

1979 The Turtles of Thailand. Bangkok: Siam Farm Zoological Garden.

O'Hara, R. B., And D. J. Kotze

2010 Do not log-transform count data. Methods in Ecology and Evolution $1: 118-122$.

PARNell, ANDREW

2014 Bchron: Radiocarbon dating, age-depth modelling, relative sea level rate estimation, and nonparametric phase modelling. $\mathrm{R}$ package version 4.1.1. http://CRAN.R-project.org/package= Bchron.

Peters, Joris, Ophélie Lebrasseur, Julia Best, Holly Miller, Tyr Fothergill, Keith Dobney, Richard M. Thomas, Mark Maltby, Naomi Sykes, Olivier Hanotte, Terry O’Connor, Matthew J. Collins, and Greger Larson

2015 Questioning new answers regarding Holocene chicken domestication in China. Proceedings of the National Academy of Sciences 112(19): E2415.

Piper, Philip J., and Ryan J. Rabett

2014 Late Pleistocene subsistence strategies in Island Southeast Asia and their implications for understanding the development of modern human behaviour, in Southern Asia, Australia and the Search for Human Origins: 118-134, ed. R. Dennell and M. Porr. Cambridge: Cambridge University Press.

POOKAJORn, Surin

1985 Ethnoarchaeology with the Phi Tong Luang (Mlabri): Forest hunters of northern Thailand. World Archaeology 17(2): 206-221.

1988 Archaeological Research of the Hoabinhian Culture or Technocomplex and its Comparison with Ethnoarchaeology of the Phi Tong Luang, a Hunter-Gatherer Group of Thailand. Ph.D. diss. University of Tübingen.

1992 The Phi Tong Luang (Mlabri): A Hunter-Gatherer Group in Thailand. Bangkok: Oden Store.

Pritchard, P.C.H., R. J. Rabett, and P. J. Piper

2009 Distinguishing species of Geoemydid and Trionychid turtles from shell fragments: Evidence from the Pleistocene at Niah Caves, Sarawak. International Journal of Osteoarchaeology 19:531550 . 
RABETT, Ryan J.

2012 Human Adaptation in the Asian Paleolithic: Hominin Dispersal and Behaviour during the Late Quaternary. Cambridge: Cambridge University Press.

Rabett, Ryan, and Graeme Barker

2010 Late Pleistocene and early Holocene forager mobility in Southeast Asia, in Southeast Asia: Essays in Honour of Ian Glover: 67-78, ed. B. Bellina, E. A. Bacus, T. O. Pryce, and J. W. Christie. Bangkok: River Books.

R Development Core Team

2014 R: A language and environment for statistical computing. R Foundation for Statistical Computing, Vienna, Austria. http://www.R-project.org.

Reimer, Paula J., Edouard Bard, Alex Bayliss, J. Warren Beck, Paul G. Blackwell, Christopher Bronk Ramsey, Caitlin E. Buck, Hai Cheng, R. Lawrence Edwards, Michael Friedrich, Pieter M. Grootes, Thomas P. Guilderson, Haflidi Haflidason, Irka Hajdas, Christine Hatté, Timothy J. Heaton, Dirk L. Hoffman, Alan G. Hogg, Konrad A. Hughen, Felix K. Kaiser, Bernd Kromer, Sturt W. Manning, Mu Niu, Ron W. Reimer, David A. Richards, E. Marian Scott, John R. Southon, Richard A. Staff, Christian S. M. Turney, and Johannes van der Plicht

2013 IntCal13 and Marine13 radiocarbon age calibration curves 0-50,000 years cal BP. Radiocarbon 55(4) : 1869-1887.

REYNOLDS, T.E.G.

1990 The Hoabinhian: A review, in Bibliographic Review of Far Eastern Archaeology: 1-30, ed. G. L. Barnes. Oxford: Oxbow Books.

Riztyan, Kotaro Kawabe, Takeshi Shimogiri, Yashuiro Kawamoto, Worawut RerkamnuayCHOKe, Takao Nishida, and Shin OKamoto

2014 Genetic diversity and ancestral relationships of red junglefowls and domestic chickens in Southeast Asia. Japan Poultry Science Association 51:369-374.

Robson, Craig

2008 Birds of Thailand. Princeton, NJ: Princeton University Press.

RSTUDIO

2014 RStudio: Integrated Development Environment for R (Version 0.98.1028) [Computer software]. Boston. Available from http://www.rstudio.org/.

Shoocongdej, Rasmi

2000 Forager mobility organization in seasonal tropical environments of western Thailand. World Archaeology 32(1): 14-40.

2006 Late Pleistocene activities at the Tham Lod Rockshelter in Highland Pang Mapha, Mae Hong Son Province, northwestern Thailand, in Uncovering Southeast Asia's Past: Selected Papers from the 10th International Conference of the European Association of Southeast Asian Archaeologists: 22-37, ed. E. Bacus, I. Glover, and V. Pigott. Singapore: NUS Press.

2010 Subsistence-settlement organization during the late Pleistocene-early Holocene: The case of Lang Kamnan Cave, western Thailand, in 50 Years of Archaeology in Southeast Asia: Essays in Honour of Ian Glover: 51-65, ed. B. Bellina, E. A. Bacus, T. O. Pryce, and J. W. Christie. Bangkok: River Books.

Solheim, Wilhelm G. II

1972 An earlier agricultural revolution. Scientific American 226(4):34-42.

Stimpson, C. M.

2009 Raptor and owl bone from Niah Caves, Sarawak: Identifications and morphological variation in the humerus and tarsometatarsus of selected raptors. International Journal of Osteoarchaeology $19: 476-490$.

2012 Local scale, proxy evidence for the presence of closed canopy forest in Northwestern Borneo in the late Pleistocene: Bones of Strategy I bats from the archaeological record of the Great Cave of Niah, Sarawak. Palaeogeography, Palaeoclimatology, Palaeoecology 331-332:136149.

TAYLOR, EDWARD H.

1970 The turtles and crocodiles of Thailand and adjacent waters: With a synoptic herptetological bibliography. The University of Kansas Science Bulletin 59(3):87-179.

Thirakhupt, Kumthorn, and Peter Paul van Dijk

1994 Species diversity and conservation of turtles of western Thailand. Natural History Bulletin of the Siam Society 42:207-259. 
Thompson, Vicki A., Ophélie Lebrasseur, Jeremy J. Austin, Terry L. Hunt, David A. Burney, Tim Denham, Nicolas J. Rawlence, Jamie R. Wood, Jamie Gongore, Linus Girdland Flink, Anna Linderholm, Keith Doney, Greger Larson, and Alan Cooper

2014 Using ancient DNA to study the origins and dispersal of ancestral Polynesian chickens across the Pacific. Proceedings of the National Academy of Sciences 111(13) : 4826-4831.

Valentin, Frédérique, Hallie R. Buckley, Estelle Herrscher, Rebecca Kinaston, Stuart Bedford, Matthew Spriggs, Stuart Hawkins, and Ken Neal

2010 Lapita subsistence strategies and food consumption patterns in the community of Teouma (Efate, Vanuatu). Journal of Archaeological Science 37 : 1820-1829.

Vetter, Holger, and Peter Paul van Dijk

2006 Turtles of the World, vol. 4: East and South Asia. Frankfurt am Main: Chimaira.

White, Joyce C.

2004 Comment on dates from a resin-coated sherd from Spirit Cave, Thailand. Antiquity 78(299) : 184-186.

2011 Cultural diversity in Mainland Southeast Asia: Introduction, in Dynamics of Human Diversity: The Case of Mainland Southeast Asia: 9-46, ed. N. J. Enfield. Canberra: Pacific Linguistics.

White, Joyce, Daniel Penny, Lisa Kealhofer, and Bernard Maloney

2004 Vegetation changes from the late Pleistocene through the Holocene from three areas of archaeological significance in Thailand. Quaternary International 113:111-132.

Wolverton, Steve

2002 NISP:MNE and \% whole in analysis of prehistoric carcass exploitation. North American Archaeologist 23(2) : 85-100.

Wolverton, Steve, Lisa Nagaoka, Julie Densmore, and Ben Fullerton

2008 White-tailed deer harvest pressure \& within-bone nutrient exploitation during the mid- to late Holocene in southeast Texas. Before Farming 2(3): 1-23.

Xiang, Hai, Jianqiang Gao, Baoquan Yu, Hui Zhou, Dawei Cai, Youwen Zhang, Ziaoyong Chen, Xi Wang, Michael Hofreiter, and Zingbo Zhao

2014 Early Holocene chicken domestication in northern China. Proceedings of the National Academy of Sciences of the United States of America 111(49): 17564-17569.

Yen, Douglas E.

1977 Hoabinhian horticulture: The evidence and the questions from northwest Thailand, in Sunda and Sahul: 567-600, ed. J. Allen, J. Golson and R. Jones. London: Academic Press.

Zeileis, A., C. Kleiber, and S. Jackman

2007 Regression models for count data in R. Journal of Statistical Software 27(8): 1-25.

\section{ABSTRACT}

This reanalysis uses the zooarchaeological assemblage recovered from Spirit Cave to understand hunter-gatherer use and occupation at the site during the PleistoceneHolocene transition. We analyze bone fragmentation, sample size, and relative abundance to establish the preservation and overall composition of the remaining fauna. Identification of several new taxa, including roundleaf bats (Hipposideros larvatus and bicolor), elongated tortoise (Indotestudo elongata), black marsh turtle (Siebenrockiella crassicollis), Burmese hare (Lepus cf. peguensis) and a potential red junglefowl (Phasianidae-?Gallus gallus) provide insights into hunter-gatherer occupation, palaeoecology, and subsistence strategies between 12,000 and 7000 years B.P. Our results indicate that Spirit Cave was occupied more sporadically than originally suggested; additionally, we identify new evidence for landscape disturbance during the early Holocene. Although this Spirit Cave zooarchaeological assemblage is incomplete, it remains an important component of Southeast Asian prehistory, providing evidence for human adaptations during a period of climatic change and instability. Keywords: Spirit Cave, zooarchaeology, NISP, MNI, Thailand, Pleistocene-Holocene transition, Hipposideros larvatus, Lepus peguensis, Siebenrockiella crassicollis. 